JAMBURA JOURNAL OF MATHEMATICS EDUCATION

Jambura J. Math. Edu. Vol. 1, No. 1, pp. 32-40, Maret 2020

Journal Homepage: http://ejurnal.ung.ac.id/index.php/jmathedu

\title{
Pengaruh Model Pembelajaran Learning Cycle dan Penalaran Formal terhadap Hasil Belajar Matematika
}

\author{
Indra Puluhulawa ${ }^{*}$, Evi Hulukati², Ali Kaku ${ }^{3}$
}

${ }_{1}^{1}$ Prodi Pendidikan Matematika, Pascasarjana, Universitas Negeri Gorontalo

Jl. Jenderal Sudirman No. 06, Kota Gorontalo, Gorontalo 96128, Indonesia

2,3 Jurusan Matematika, Fakultas MIPA, Universitas Negeri Gorontalo

Jl. Prof. Dr. Ing. B. J. Habibie, Moutong, Tilongkabila, Kabupaten Bone Bolango, Gorontalo 96119, Indonesia

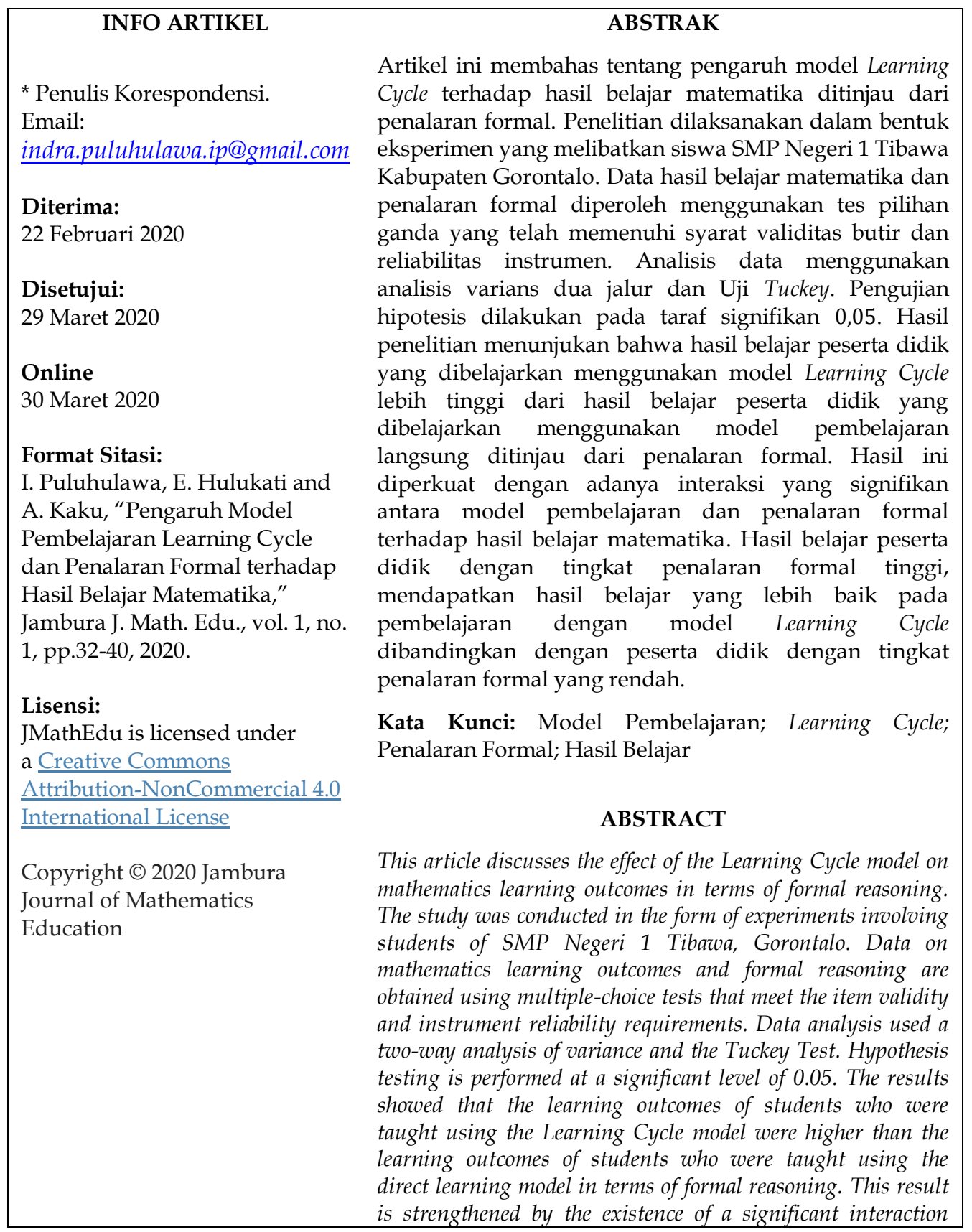




between learning models and formal reasoning towards
mathematics learning outcomes. Student learning outcomes
with high formal reasoning levels, get better learning outcomes
in learning with the Learning Cycle model compared to
students with low formal reasoning levels.
Keywords: Learning Model; Learning Cycle; Formal
Reasoning; Learning Result

\section{Pendahuluan}

Penyelenggaraan pembelajaran matematika tidaklah mudah, karena fakta di lapangan menunjukkan bahwa tidak sedikit siswa yang mengalami kesulitan dalam memahami materinya. Oleh sebab itu guru harus perlu berusaha untuk mencari tahu apa yang menyebabkan mereka merasakan hal seperti itu. Hasil pengamatan selama ini diketahui bahwa ketidaktertarikan mereka pada matematika itu karena mata pelajaran ini dinilai rumit dan membosankan, bahkan mereka sering lupa pada konsep yang telah diberikan, akibatnya mereka tidak mengerjakan tugas yang diberikan oleh guru. Meskipun demikian tidak sedikit siswa yang gemar dan senang belajar matematika.

Selanjutnya jika dicermati, kebanyakan siswa mengalami kesulitan dalam mengaplikasikan matematika kedalam situasi kehidupan sehari-hari. Mengaitkan pengalaman kehidupan nyata anak dengan ide-ide matematika dalam pembelajaran di kelas penting dilakukan agar pembelajaran lebih bermakna dan hasil belajar matematika dapat meningkat.

Harapan kita semua adalah adanya peningkatan kualitas pelaksanaan pembelajaran yang berbanding lurus dengan peningkatan hasil belajar siswa. Namun kenyataan yang terjadi justru sebaliknya. Berdasarkan data pada sekolah sasaran penelitian, ratarata hasil ujian nasional mata pelajaran matematika adalah 37,14 yang belum mencapai hasil yang diharapkan. Nilai matematika siswa belum mencapai standar nasional sehingga menempatkan mata pelajaran ini pada urutan terendah dibandingkan mata pelajaran lain. Banyak hal yang dapat menjadi faktor rendahnya hasil belajar matematika bisa dari segi motivasi belajarnya [1], media pembelajarannya [2], model pembelajaran yang digunakan, kemampuan komunikasi dan pemecahan masalah peserta didiknya [3], atau bahkan dari segi persepsi peserta didik itu sendiri [4]. Disamping itu, penting juga untuk melihat bagaimana kemampuan penalaran matematis dan gaya kognitif peserta didik [5].

Mencermati hal tersebut maka diperlukan upaya untuk memperbaiki dan meningkatkan mutu hasil belajar tersebut yakni kita perlu melihat kembali kegiatan pembelajaran yang dilakukan selama ini, apakah kegiatannya telah menginspirasi siswa dalam berpikir kritis, kreatif, analistis, dan tepat dalam mengidentifikasi, memahami, memecahkan masalah, serta mengaplikasikan materi yang dipelajarinya.

Berdasarkan hasil pengamatan, langkah-langkah dalam proses pembelajaran khususnya penyajian konsep matematika belum terstruktur dengan baik. Langkahlangkah dalam pembelajaran tersebut diduga menyebabkan banyak siswa mengalami kesulitan dalam matematika. Salah satu materi pada mata pelajaran matematika adalah bangun ruang sisi lengkung yang merupakan salah satu pokok bahasan pada semester genap kelas IX SMP. Materi ini membutuhkan model pembelajaran yang tepat. Jika tidak, banyak siswa yang kurang berminat dalam kegiatan pembelajaran. Hal ini diduga berdampak pada rendahnya hasil belajar mereka. Data yang diperoleh 
dari sekolah sasaran penelitian ini pada tahun sebelumnya menunjukkan bahwa nilai rata-rata siswa kelas IX pada pokok bahasan bangun ruang sisi lengkung adalah ratarata 50,30. Disamping itu kondisi pembelajaran sekarang, guru banyak memilih model pembelajaran langsung. Pembelajaran langsung dimaksud adalah pembelajaran yang didominasi oleh guru dalam bentuk ceramah, tanya jawab dan pemberian latihan menjawab soal-soal matematika. Cara mengajar seperti itulah yang diduga menghambat kreativitas siswa dalam melakukan kegiatan belajar matematika sehingga kegiatan pembelajaran kurang menantang dan kurang dapat membangkitkan minat belajar siswa.

Berdasarkan uraian di atas dapat disimpulkan bahwa yang menyebabkan sulitnya matematika bagi siswa diduga karena pemilihan model pembelajaran yang belum tepat. Sehubungan dengan hal tersebut, maka dirasa perlu untuk mencari solusi dalam mengatasi permasalahan tersebut. Salah satunya adalah dengan menggunakan model pembelajaran Learning Cycle. Model tersebut merupakan salah satu model pembelajaran yang berlandaskan pada pandangan konstruktivisme [6]. Pandangan ini berasumsi bahwa mengajar bukan sebagai proses dimana gagasan-gagasan guru diteruskan pada para siswa, melainkan sebagai proses untuk mengubah dan membangun gagasan-gagasan siswa yang sudah ada. Dengan demikian, proses belajar mengajar lebih berpusat pada siswa (student centered) dari pada teacher centered. Dengan kata lain pembelajaran berpusat pada siswa dan guru berperan sebagai fasilitator. Diharapkan dengan menggunakan model pembelajaran tersebut akan terjadi peningkatan hasil belajar dan minat siswa terhadap matematika khususnya disekolah sasaran penelitian ini.

Model pembelajaran Learning Cycle adalah model pembelajaran yang terdiri fase-fase atau tahap-tahap kegiatan yang diorganisasikan sedemikian rupa sehingga siswa dapat menguasai kompetensi-kompetensi yang harus dicapai dalam pembelajaran dengan jalan berperan aktif. Model pembelajaran Learning Cycle merupakan salah satu model pembelajaran dengan pendekatan konstruktivistik dan pertama kali diperkenalkan oleh Robert Karplus terdiri dari tiga fase/tahap kemudian berkembang menjadi lima fase/tahap yaitu: fase pembangkitan minat (engagement), fase eksplorasi (exploration), fase penjelasan (explanation), fase elaborasi (elaboration), dan fase evaluasi (evaluation) [7].

Selain belum diterapkannya model pembelajaran Learning Cycle, terdapat faktor lain yang juga mempengaruhi hasil belajar siswa. Faktor tersebut adalah penalaran formal. Penalaran formal merupakan kapasitas siswa untuk melakukan operasi-operasi formal yang meliputi berpikir kombinatorial, berpikir proporsi, berpikir koordinasi, berpikir probabilitas, dan berpikir korelasi.

Hal lain yang perlu dicermati oleh guru dalam melaksanakan pembelajaran adalah penalaran formal yang berbeda-beda dimiliki oleh siswa. Proses Pembelajaran akan terlaksana dengan baik bila informasi tentang penalaran formal siswa sudah dimiliki guru. Piaget menyatakan bahwa anak-anak dianggap siap mengembangkan konsep khusus jika memperoleh skemata yang diperlukan. Hal ini berarti anak-anak tidak dapat belajar (tidak dapat mengembangkan skemata) jika tidak memiliki keterampilan kognitif. Mencermati hal tersebut maka dalam tulisan ini dibahas tentang pengaruh model Learning Cycle terhadap hasil belajar matematika ditinjau dari penalaran formal. 


\section{Metode}

Penelitian ini dilaksanakan di SMP Negeri 1 Tibawa, Jln. Kabupaten Gorontalo, Provinsi Gorontalo pada semester genap tahun pelajaran 2018/2019. Jumlah sampel dalam penelitian ini adalah 121 orang, dengan menggunakan teknik Multiple Stage Random Sampling. Jenis penelitian adalah eksperimen semu dan desain penelitian ini adalah Treatment by Level, analisis varian (anava) faktorial $2 \times 2$ menggunakan varians dua jalur dan dilanjutkan dengan uji Tukey. Variabel bebas dalam penelitian ini adalah model pembelajaran Learning Cycle, variabel terikat dalam penelitian ini adalah hasil belajar matematika, dan penalaran formal peserta didik sebagai variabel moderator yang digunakan untuk membedakan antara kelompok penalaran formal tinggi dan penalaran formal rendah. Pengumpulan data hasil belajar dan penalaran formal peserta didik menggunakan tes tertulis pilihan ganda.

\section{Hasil dan Pembahasan}

\subsection{Hasil Penelitian}

Hasil penelitian diringkas dalam betuk rekap ukuran statistik data seperti pada Tabel 1 berikut ini.

Tabel 1. Deskripsi data hasil belajar matematika

\begin{tabular}{ccccccccc}
\hline Data & $\mathrm{n}$ & $\begin{array}{c}\text { Skor } \\
\text { Min }\end{array}$ & $\begin{array}{c}\text { Skor } \\
\text { Max }\end{array}$ & $\begin{array}{c}\text { Mean } \\
\bar{x}\end{array}$ & Modus & $\begin{array}{c}\text { Median } \\
(\text { Me })\end{array}$ & $\begin{array}{c}\text { St.Dev } \\
(\mathrm{s})\end{array}$ & $\begin{array}{c}\text { Varians } \\
\left(\mathrm{s}^{2}\right)\end{array}$ \\
\hline A1 & 30 & 8 & 19 & 13,63 & 12,36 & 13,25 & 3.08 & 9,49 \\
A2 & 30 & 7 & 17 & 11,90 & 12,90 & 12,00 & 2,60 & 6,76 \\
B1 & 30 & 7 & 19 & 13,50 & 11,83 & 12,50 & 3,53 & 12,46 \\
B2 & 30 & 8 & 17 & 12,17 & 12,27 & 12,17 & 2.26 & 5,10 \\
A1B1 & 15 & 13 & 19 & 16.23 & 16,50 & 16,33 & 1,77 & 3,13 \\
A1B2 & 15 & 8 & 13 & 11,23 & 11,50 & 11,33 & 1,77 & 3,13 \\
A2B1 & 15 & 7 & 14 & 10,57 & 11,17 & 10,70 & 2,05 & 4,20 \\
A2B2 & 15 & 9 & 17 & 13,30 & 13,00 & 13,30 & 2,29 & 5,24 \\
\hline
\end{tabular}

Pengujian hipotesis penelitian ini dilakukan dengan teknik Analisis Varians dua Jalur (ANAVA $2 \times 2$ ), kemudian dilakukan uji lanjut dengan menggunakan uji Tuckey untuk menentukan kebermaknaan interaksi diantara variabel penelitian.

Adapun hasil perhitungan Anava 2 jalur dan uji Tukey disajikan dalam Tabel 2 dan Tabel 3.

Tabel 2. Hasil perhitungan ANAVA data hasil belajar matematika

\begin{tabular}{lrrrrcc}
\hline $\begin{array}{l}\text { Sumber } \\
\text { Variansi }\end{array}$ & $\mathrm{Jk}$ & $\mathrm{dk}$ & $\mathrm{Rk}$ & \multicolumn{1}{c}{$\mathrm{F}_{\text {hitung }}$} & $\begin{array}{c}\mathrm{F}_{\text {tabel }} \\
(\alpha=0,05)\end{array}$ & $\begin{array}{c}\mathrm{F}_{\text {tabel }} \\
(\alpha=0,01)\end{array}$ \\
\hline Kolom (K) & 48,6000 & 1 & 48,6000 & 12,4085 & 4,01 & 7,12 \\
Baris (B) & 21,6000 & 1 & 21,6000 & 5,5149 & 4,01 & 7,12 \\
$(\mathrm{BK})$ & 232,0667 & 1 & 232,0667 & 59,2511 & 4,01 & 7,12 \\
Dalam (d) & 219,3333 & 56 & 3,9167 & - & - & - \\
Total (T) & 521,6000 & 59 & 306,1833 & - & - & - \\
\hline
\end{tabular}


I. Puluhulawa, dkk | Pengaruh Model Pembelajaran Learning Cycle dan Penalaran Formal

Tabel 3. Ringkasan hasil perhitungan uji Tukey $(\alpha=0,05)$

\begin{tabular}{ccccc}
\hline No. & $\begin{array}{c}\text { Kelompok } \\
\text { Perbandingan }\end{array}$ & $\mathrm{Q}_{\text {hitung }}$ & $\mathrm{Q}_{\mathrm{t}(0,05)}$ & Kesimpulan \\
\hline 1. & $\mathrm{A}_{1} \mathrm{~B}_{1}$ dengan $\mathrm{A}_{2} \mathrm{~B}_{1}$ & 11,22 & 4,08 & Signifikan \\
2. & $\mathrm{A}_{1} \mathrm{~B}_{2}$ dengan $\mathrm{A}_{2} \mathrm{~B}_{2}$ & 4,17 & 4,08 & Signifikan \\
\hline
\end{tabular}

\subsection{Pembahasan}

Berdasarkan hasil penelitian di atas maka dikemukakan pembahasan terhadap hal-hal tersebut yang meliputi:

1) Perbedaan hasil belajar peserta didik yang mengikuti model pembelajaran

Learning Cycle dan mengikuti model pembelajaran langsung

Sebagaimana dijelaskan di atas bahwa hasil pengujian hipotesis pertama menunjukkan terdapat perbedaan hasil belajar matematika peserta didik yang menggunakan model pembelajaran Learning Cycle dan yang dibelajarkan dengan menggunakan model pembelajaran langsung. Secara keseluruhan penggunaan model pembelajaran Learning Cycle terhadap hasil belajar matematika lebih tinggi dari penggunaan model pembelajaran langsung.

Hipotesis ini menunjukkan bahwa model pembelajaran Learning Cycle menciptakan ketertarikan peserta didik dan memberikan kesempatan kepada peserta didik untuk dapat berpikir dan bekerja. Dalam model pembelajaran Learning Cycle peserta didik lebih banyak bekerja baik secara mandiri maupun kelompok, melakukan percobaan (secara ilmiah), melakukan pengamatan, mengumpulkan data, sampai pada membuat suatu kesimpulan dari percobaan yang dilakukan. Dalam konteks ini peserta didik harus membaca, menulis, mendiskusikan, atau terlibat secara aktif dalam pemecahan berbagai masalah (they must read, write, discuss, or be engaged in soving problems).

Lebih dari itu pada fase penjelasan (Explanation) peserta didik dilibatkan secara aktif dalam kegiatan melengkapi, menyempurnakan, dan mengembangkan konsep yang diperoleh, menjelaskan konsep yang dipahaminya dengan kata-katanya sendiri, menunjukkan contoh-contoh yang berhubungan dengan konsep untuk melengkapi penjelasannya, serta bisa memperkenalkan istilah-istilah baru yang belum diketahui, sehingga, peserta didik dapat meningkatkan pemahaman konsep yang baru diperolehnya. Hal senada dikemukakan oleh Fajaro [8] bahwa model pembelajaran Learning Cycle memiliki beberapa kelebihan diantaranya a) merangsang peserta didik untuk mengingat kembali materi pelajaran yang telah mereka dapatkan sebelumnya, b) memberikan motivasi kepeda peserta didik untuk lebih aktif dalam pembelajaran dan menambah rasa keingintahuan, c) melatih peserta didik belajar menemukan konsep melalui kegiatan eksperimen, d) melatih peserta didik untuk menyampaikan secara lisan konsep yang telah mereka pelajari, e) memberi kesempatan kepada peserta didik untuk berpikir, mencari, menemukan dan menjelaskan contoh penerapan konsep yang telah dipelajari.

Keunggulan model pembelaja ran Learning Cycle yaitu suasana pembelajaran disetting dalam suasana menyenangkan (joyful learning). Kondisi yang menyebabkan suasana pembelajaran menjadi dinamis dan peserta didik leluasa beraktivitas dan tidak terbebani dengan tekanan fisik dan mental. Proses belajar tidak mungkin dapat 
berlangsung dalam suasana penuh tekanan fisik dan mental. Salah satu model pembelajaran yang dapat berlangsung efektif jika dilakukan dalam suasana yang menyenangkan. Pandangan ini jelas menunjukkan bahwa model pembelajar an Learning Cycle memiliki keunggulan dibandingkan dengan model pembela jaran langsung yang cenderung menjerat peserta didik dengan aturan-aturan yang kaku dalam proses pembelajaran sehingga suasana kelas menjadi tegang, peserta didik berkurang semangat belajar sehingga berpengaruh terhadap hasil belajarnya.

Ditinjau dari sisi pembelajaran, model pembelajaran langsung lebih berorientasi pada penyelesaian materi pelajaran sesuai dengan batas waktu yang telah ditetapkan dalam kurikulum ataupun dalam program yang telah dirancang sebelumnya. Pembelajaran langsung cenderung menyajikan konsep secara abstrak sehingga sulit dipahami peserta didik. Guru pun jarang mendekatkan peserta didik dengan lingkungannya, sehingga sebagian besar konsep yang diperoleh sulit diorientasikan kedalam kehidupan nyata. Sedangkan model pembelajaran Learning Cycle dengan visi utama students-centered mengubah paradig ma tersebut menjadi pembelajaran yang menyenangkan dengan pemberian kesempatan kepada peserta didik untuk melakukan aktivitas belajar sehingga tertantang untuk menyelesaikan masalah yang berhubungan dengan matematika.

2) Pengaruh interaksi antara model pembelajaran dengan penalaran formal terhadap hasil belajar peserta didik

Hasil pengujian hipotesis kedua menunjukkan bahwa terdapat interaksi antara model pembelajaran dengan penalaran formal peserta didik yang memberikan pengaruh berbeda terhadap hasil belajar matematika. Pengaruh interaksi menunjukkan bahwa antara model pembelajaran dan penalaran formal mempunyai sinergi yang positif terhadap hasil belajar matematika. Hal tersebut dapat dilihat pada hasil uji hipotesis ketiga yang menunjukkan bahwa peserta didik yang memiliki penalaran formal tinggi yang menggunakan model pembelajaran Learning Cycle memiliki hasil belajar yang lebih tinggi, dibandingkan dengan peserta didik yang memiliki penalaran formal tinggi yang dibelajarkan dengan menggunakan model langsung. Demikian pula hasil uji hipotesis keempat menunjukkan bahwa peserta didik yang memiliki penalaran formal rendah yang menggunakan model langsung memiliki hasil belajar yang lebih tinggi, dibandingkan dengan peserta didik yang memiliki penalaran formal rendah yang menggunakan model pembelajaran Learning Cycle. Dengan adanya interaksi ini menunjukkan bahwa model pembelajaran secara signifikan telah mampu meningkatkan hasil belajar peserta didik. Dengan demikian dapat dinyatakan bahwa model pembelajaran Learning Cycle lebih cocok digunakan untuk peserta didik yang memiliki penalaran formal tinggi. Sebaliknya model pembelajaran langsung lebih cocok digunakan untuk peserta didik yang memiliki penalaran formal rendah.

3) Perbedaan hasil belajar peserta didik yang memiliki penalaran formal tinggi, dengan mengikuti model pembelajaran Learning Cycle dan mengikuti model pembelajaran langsung

Berdasarkan hasil analisis data, telah terbukti bahwa terdapat perbedaaan hasil belajar peserta didik yang memiliki penalaran formal tinggi yang menggunakan model pembelajaran Learning Cycle dan model pembelajaran langsung. Selanjutnya terbukti 
bahwa hasil belajar peserta didik yang memiliki penalaran formal tinggi yang menggunakan model Learning Cycle memiliki skor rata-rata 16,23 lebih tinggi daripada hasil belajar peserta didik yang menggunakan model pembelajaran langsung dengan skor rata-rata 10,57. Hal ini juga ditunjukkan oleh angka Tukey (Q) sebesar 11,22 yang ternyata signifikan. Pembelajaran yang menggunakan model Learning Cycle sangat tepat diterapkan pada peserta didik yang memiliki penalaran formal tinggi dibandingkan dengan pembelajaran menggunakan model pembelajaran langsung. Hal ini menunjukkan bahwa model Learning Cycle memiliki keunggulan dalam membentuk peserta didik yang memiliki penalaran formal tinggi untuk menjadi pembelajar yang mandiri sehingga aktif berpikir, berbuat dalam memecahkan masalah. Dalam konteks yang bersamaan peserta didik akan trampil dalam mengambil keputusan, melakukan analisis suatu masalah sehingga memahami substansi permasalahan yang dihadapi yang pada gilirannya akan berimplikasi pada peningkatan hasil belajarnya.

Jika dicermati keadaan tersebut sangat nyata karena model pembelajaran Learning Cycle dengan karakteristik utamanya pembelajaran yang memberikan kesempatan kepada peserta didik untuk aktif dalam memperoleh pengamalan belajar yang tersedia atau difasilitasi guru. Made [7] mengemukakan bahwa perbedaan mendasar antara model pembelajaran siklus belajar (Learning Cycle) dengan pembelajaran langsung adalah guru lebih banyak bertanya daripada memberi tahu. Misalnya pada waktu akan melakukan eksperimen terhadap suatu permasalahan, guru tidak memberi petunjuk langkah-langkah yang harus dilakukan peserta didik, tetapi guru mengajukan pertanyaan penuntun tentang apa yang akan dilakukan peserta didik, apa alasan peserta didik merencanakan atau memutuskan perlakuan yang demikian. Dengan demikian, kemampuan analisis, evaluatif, dan argumentatif pesrta didik dapat berkembang dan meningkat secara signifikan. Hal ini berarti jika penggunaan model pembelajaran Learning Cycle pada peserta didik yang memiliki penalaran formal tinggi hasil belajarnya akan lebih tinggi dari pada penerapan model pembelajaran langsung.

4) Perbedaan hasil belajar peserta didik yang memiliki penalaran formal rendah dengan mengikuti model pembelajaran Learning Cycle dan mengikuti model pembelajaran langsung

Hipotesis keempat telah terbukti bahwa hasil belajar peserta didik yang mempunyai penalaran formal rendah yang menggunakan model pembelajaran Learning Cycle lebih rendah dari hasil belajar menggunakan model pembelajaran langsung. Hal ini sesuai dengan hasil perhitungan uji Tukey (Q) sebesar 4,17 yang ternyata signifikan. Dari hasil uji Tukey ini menunjukkan bahwa hasil belajar peserta didik yang mempunyai penalaran formal rendah yang menggunakan model pembelajaran langsung yang memiliki skor rata-rata 13,30 ternyata lebih tinggi dari yang dibelajarkan dengan menggunakan model Learning Cycle yang memiliki skor rata-rata 11,23. Berdasarkan temuan penelitian ini mengindikasi kan bahwa pembelajaran mengguna kan model pembelajaran langsung mampu meningkatkan hasil belajar peserta didik yang memiliki penalaran formal rendah.

Satu hal yang menjadi catatan dalam penelitian ini adalah beberapa peserta didik yang memiliki penalaran formal rendah mengemukakan bahwa mereka butuh contohcontoh soal sekaligus dengan contoh jawaban daripada harus melakukan aktivitas untuk menemukan sendiri jawaban atas soal-soal tersebut melalui kegiatan kelompok 
atau melalui aktivitas individual. Kholik [9] mengemukakan bahwa kelebihan pembelajaran langsung adalah: a) berbagai informasi yang tidak mudah ditemukan di tempat lain, b) menyampaikan informasi dengan cepat, c) membangkitkan minat akan informasi, d) mengajari peserta didik yang cara belajar terbaiknya dengan mendengarkan, e) mudah digunakan dalam proses belajar mengajar. Dalam konteks ini model langsung memiliki sisi tertentu yang menjadi keunggulannya diantaranya terjadi pada anak yang memiliki penalaran formal rendah yang cenderung mengharapkan untuk selalu dipandu dalam segala aktivitasnya. Sedangkan peserta didik yang senang dengan aktivitas baik secara kelompok maupun individual lebih suka dengan model pembelajaran Learning Cycle.

Temuan ini sekaligus membukti kan bahwa model pembelajaran langsung tidak selamanya buruk. Model pembelajaran ini ternyata tepat digunakan terhadap anak yang memiliki penalaran formal rendah. Anak yang memiliki penalaran formal rendah biasanya lebih senang mendengar penjelasan guru dari pada berbuat atau melakukan kegiatan belajar secara mandiri sebagaimana yang diharapkan dalam model pembelajaran Learning Cycle.

\section{Kesimpulan}

Hasil penelitian menunjukan bahwa hasil belajar peserta didik yang dibelajarkan menggunakan model Learning Cycle lebih tinggi dari hasil belajar peserta didik yang dibelajarkan menggunakan model pembelajaran langsung ditinjau dari penalaran formal. Hasil ini diperkuat dengan adanya interaksi yang signifikan antara model pembelajaran dan penalaran formal terhadap hasil belajar matematika. Hasil belajar peserta didik dengan tingkat penalaran formal tinggi, mendapatkan hasil belajar yang lebih baik pada pembelajaran dengan model Learning Cycle dibandingkan dengan peserta didik dengan tingkat penalaran formal yang rendah.

\section{Referensi}

[1] C. Magelo, E. Hulukati, and I. Djakaria, "Pengaruh Model Pembelajaran Open Ended terhadap Kemampuan Berpikir Kreatif Matematik Ditinjau dari Motivasi Belajar," Jambura J. Math., vol. 2, no. 1, pp. 15-21, 2020.

[2] V. Damopolii, N. Bito, and R. Resmawan, "Efektivitas Media Pembelajaran Berbasis Multimedia pada Materi Segiempat," Algoritm. J. Math. Educ., vol. 1, no. 2, pp. 74-85, 2019.

[3] E. Hulukati, "Mengembangkan kemampuan komunikasi dan pemecahan masalah matematika siswa SMP melalui model pembelajaran generatif," Universitas Pendidikan Indonesia, 2005.

[4] R. Resmawan, "Hubungan antara Pesepsi Mahasiswa terhadap Keterampilan Dosen dalam Mengelola Kelas dengan Hasil Belajar Mahasiswa Jurusan Pendidikan Matematika," J. Euler, vol. 2, no. 2, pp. 129-134, 2014.

[5] N. A. Yunus, E. Hulukati, and I. Djakaria, "Pengaruh Pendekatan Kontekstual Terhadap Kemampuan Penalaran Matematis Ditinjau dari Gaya Kognitif Peserta Didik," Jambura J. Math., vol. 2, no. 1, pp. 30-38, 2020.

[6] Trianto, Model Pembelajaran Inovatif Berorientasi Konstruktifistik. Jakarta: Prestasi Pustaka, 2011. 
I. Puluhulawa, dkk | Pengaruh Model Pembelajaran Learning Cycle dan Penalaran Formal

[7] L. W. Trowbridge and R. W. Bybee, Teaching Secondary School Science: Strategies for Developing Scientific Literacy. New York: Pearson Prentice Hall, 1996.

[8] F. Fajaroh and I. W. Dasna, Model-Model Pembelajaran Inovatif: Pembelajaran dengan Model Siklus Belajar (Learning Cycle). Malang: UM Press, 2007.

[9] M. Kholik, Metode Pembelajaran Konvensional. Bandung: Rieneka Cipta, 2011. 